\title{
AGE AND ACADEMIC PERFORMANCE OF THE PRE-DEGREE STUDENTS OF THE UNIVERSITY OF SOKOTO
}

\author{
by \\ Faruk Aliyu Kalgo \\ Faculty of Education, \\ University of Sokoto, Nigeria.
}

\begin{abstract}
Age is one of the criteria being used by the University of Sokoto for admission into its predegree programmes. This research was conducted to find out the influence of age on the academic performance of the pre-degree students. Students' age and aggregate of their scores on pre-degree examinations were used. Students, 17 years - 19 years were considered 'younger' while 20 years and above were considered 'older'. A total of 360 pre-degree out of 509 students were used. Analysis of variance carried out revealed that younger students performed significantly better than older students in three of the four cases.
\end{abstract}

\section{BACKGROUND:}

Several criteria other than their academic qualifications are taken into account while considering applicants for admission into the pre-degree courses of the University. For example, G.C.E. O-Level and West African School Certificate holders, who have been out of school for a period of five years are considered unsuitable for pre-degree studies. Consequently, age has become one of the criteria for selecting students into the pre-degree courses.

Researches have been conducted by educationists and psychologists on the age and academic performance of students at various levels of the educational ladder. Relationships between age and academic performance were, however, not conclusive. Intellectual and academic abilities have been found by some to be associated with age. In other words, one's intellectual and academic capability increases or improves with the increasing age. However, others found the opposite, that as one gets older, his intellectual and academic abilities also decrease.

Wechsler, (1955) transformed 11 subtests scores from Wechsler Adult Intelligence Scale (WAIS) into standard scores with mean 10 and standard deviation 3. Five hundred (500) of between 20 and 34 years and 475 of 69 years and over persons were included in the standardization sample. He found that the scores reach a peak between the ages of 20 and 34 and then decline slowly un ii: 60 . He argued that at any point in time, older groups would have received less education than younger groups. 
However, longitudinal studies (Campbell, 1965 and Burns, 1966) based on retests of the same persons over periods of 5 to 40 years have revealed that, the scores tend to improve with age. They argued that, as, the individual grows older, he is exposed to cultural changes that may improve his performance on intelligence and academic tests.

Itakura, (1962) compared the scholastic records in a Japanese University of three groups of candidates - the new leavers (those who left the senior high school in the year of the entrance examination), the one-year RONIN (those who are admitted one year after high school) and the RONIN of two or more years. In any of the items, the new leavers were superior. This order is thus new leavers performed better than one-year RONIN, who in turn performed better than RONIN of two or more years. This indicated that; the age at which one gains admission into the University can influence his level of performance in scholastic subjects.

Tyler, (1965) also confirmed that intellectual abilities continue to increase into early adulthood if adequate educational stimulation is provided. Throughout the middle ages of life, intellectual powers remain about the same level with some apparent stability resulting from slight increases in some abilities and slight decreases in others. From fifty (50) on, some decline in mental ability possibly occurs, and during. 70's and 80's the effects are usually apparent.

In another development, Schaie and Strother (1968) in their cross-cultural comparison between 25 men and 25 women at each 5 -year age interval from 20 to 70 in a battery of tests, showed significant intergeneration differences on all tests. The implication is the fact that, those born and reared more recently performed better than those born and reared at an earlier time period. Kapur, (1972) supportec this in his analysis of the poor performance of older students, that, the older students are out of touch with academic pursuits after leaving school. Kapur, (1972) who further, arbitrarily divided his sample into 3 categories: younger (17 years old), middle (18 and 19 years) and older (20 and above years), found that under 20 's do better than over 20 's academically. $\mathrm{He}$ found that - "a high proportion of students in the older group fail or drop-out and when the younger and middle were combined and compared with the older age group, the result was statistically significant", (Kapur, 1972:361).

Studies conducted by Von de Embse and Childs (1979) and Frerichs at al (1981) revealed that older students were more successful than younger students. Von de Embse and Childs (1979) studied the effects of chronological age on academic performance using 517 undergraduate students of Midwest State University. They found that College students 28 years or older were more likely than younger students to be among the high achievers. Similarly, Frerichs et al (1981) using 513 developmental maths students at 8 Illinois Community Colleges, found that successful students tended to be older than the unsuccessfut students. 
However, the study conducted by Isyaku, (1983) in Kano, revealed the opposite - younger students were successful. He used 239 old-age students and 195 young-age students of the Bayero University Kano. The analysis of the data showed no significant differences between younger and older students. However, in almost all cases, younger students ( 23 and below) obtained a higher grade point average (GPA).

These researches have shown that age contributes immensely to the academic impediments or progress. Academic performance was associated with younger age while academic problems were related to older age. Others have shown that, as the age increases, one's level of academic ability also improves. It is in the light of these, that this research was conducted to,find out the effects of age (chronological age) on the academic performances of the Pre-degree students of University of Sokoto. Therefore the research has the following null hypothesis - that older students will not perform significantly better than younger students.

\section{METHODOLOGY}

Data relevant to the study was collected from the Academic Office of the University. This included students' age at the time of entering the Pre-degree and their scores on various subjects offered both in Pre-degree I and II.

A simple random sampling was used to select 360 students out of 509 students (whose records were complete). The breakdown of the sample is as follows:-

$$
\begin{aligned}
& \text { Pre-degree I }(81 / 82)-90 \\
& \text { Pre-degree II }(82 / 83)-90 \\
& \text { Pre-degree I }(82 / 83)-90 \\
& \text { Pre-degree II }(83 / 84)-90
\end{aligned}
$$

The age of the students was divided into two categories: younger and older students. The younger students were from 17 years to 19 years and the older students from 20 years above. This decision was made because conventionally, some pupils entered primary school at the age of 7 and others at 6 . Similarly, some did spend 7 or 6 years in primary school before going to a post primary institution to spend 5 years. In view of this, the researcher used calculations to arrive at the aforementioned decision: 


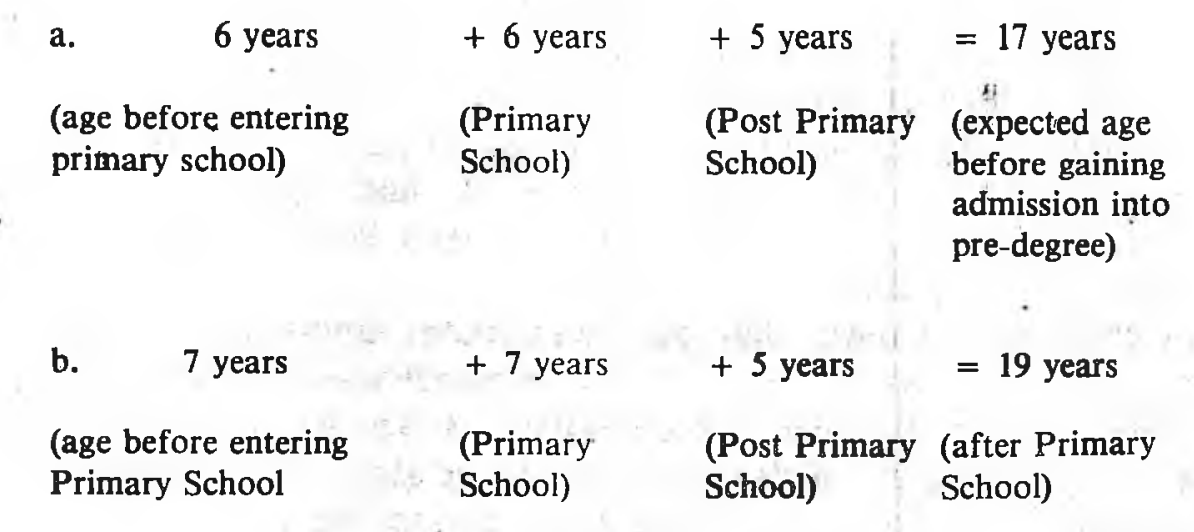

The University admits students who are 17 years old at the time of entering into the Pre-degree. It was categorically stated that, "no person undęr the age of seventeen years may be admitted to the University as a student" (Regulation For Admission Into the University, and University of Sokoto Calendar 1981/82 - 1982/83, page 94). It was therefore decided that any student who entered the University at $17-19$ years was considered young and anyone who entered at 20 and above was considered old. The cut-off point for the two groups $17-19$ years and 20 years an above was justified by the calculations given. Admittedly, one can hardly appreciate or see differences between 19 years and 20 years especially in relation to academic performance. For the research purposes, the cut-off point was used in order to have a meaningful basis for comparison. Suppose we say the cut-off point is 21 years, those in the 20-year category will definitely not be represented. Younger students were given code (1) and older students code (2).

Analysis of variance (ANOVA) was used to analyse the data. An SPSS (Statistical Package for Social Sciences) computer sub-programme ANOVA was used to find out if there are significant differences in the performance of the two age groups. Analysis of variance was used instead of the T-test of significance because the data consisted of unequal cell frequencies which a T-test could not effectively handle. ANOVA could also take care of the effects of covariates and could handle means of more than two samples. The one percent and five percent points were used as levels of significance.

\section{DATA ANALYSIS AND DISCUSSION:}

Analysis of variance was carried out for each of the group of Pre-degree students to test the null hypothesis, as shown in the following tables:

a. Pre-degree I $(81 / 82)$ 
Table I

Analysis of Variance

\begin{tabular}{llcccc}
\hline $\begin{array}{l}\text { Source of } \\
\text { Variation }\end{array}$ & $\begin{array}{l}\text { Sum of } \\
\text { Squares }\end{array}$ & DF & Mean Square & $\begin{array}{l}\text { F Level of } \\
\text { Significance }\end{array}$ \\
\hline $\begin{array}{l}\text { Between } \\
\text { groups }\end{array}$ & 6918.797 & 1 & 6918.797 & 8.127 & 0.01 \\
\hline $\begin{array}{l}\text { Within } \\
\text { groups }\end{array}$ & 74920.367 & 88 & 851.368 & \\
\hline Total & 81839.164 & 89 & & & \\
\hline
\end{tabular}

The anaysis of variance (Table I) for Pre-degree I (81/82) showed significant differences in the performance of younger and older students. This difference was better evident in Table II.

\begin{tabular}{lccc} 
& \multicolumn{2}{c}{ Table II } \\
& & Age & \\
& & & $\mathrm{N}$ \\
Younger & 1 & 40 & 187.63 \\
Older & 2 & 50 & 169.98
\end{tabular}

The mean of younger students is conspicuously higher than the mean of older students which signifies the differences in their performances in favour of younger students.

b. Pre-degree II $(82 / 83)$

Table III

Analysis of Variance

\begin{tabular}{lrrrrr}
\hline $\begin{array}{l}\text { Source of } \\
\text { Variation }\end{array}$ & $\begin{array}{l}\text { Sum of } \\
\text { Squares }\end{array}$ & DF & Mean Square & F & $\begin{array}{l}\text { Level of } \\
\text { Significance }\end{array}$ \\
\hline $\begin{array}{l}\text { Between } \\
\text { Groups }\end{array}$ & 31.246 & 1 & 31.246 & 0.077 & NS \\
\hline $\begin{array}{l}\text { Within } \\
\text { groups }\end{array}$ & 35627.379 & 88 & 404.857 & & \\
\hline Total & 35658.625 & 89 & & \\
\hline
\end{tabular}


In Pre-degree I $(82 / 83)$ the analyses have shown no significant differences in the performances of younger and older students. This lack of significant differences was ascertained in Table IV.

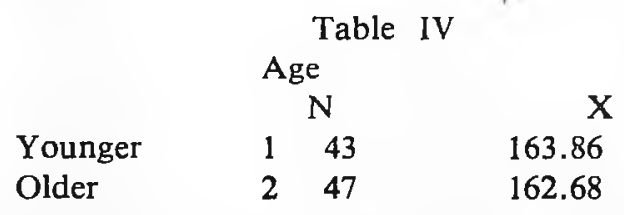

It shows that the mean of younger students was slightly higher than the mean of older students (by 1.18). But the difference was not statistically significant to warrant the superiority of the younger students.

c. Pre-degree I $(82 / 83)$

Table V

Analysis of Variance

\begin{tabular}{llllll}
\hline $\begin{array}{l}\text { Source of } \\
\text { Variation }\end{array}$ & $\begin{array}{l}\text { Sum of } \\
\text { Squares }\end{array}$ & DF & Mean Square & F & $\begin{array}{l}\text { Level of } \\
\text { Significance }\end{array}$
\end{tabular}

\begin{tabular}{lccccc}
\hline $\begin{array}{l}\text { Between } \\
\text { groups }\end{array}$ & 5994.279 & 1 & 5994.279 & 9.294 & 0.01 \\
$\begin{array}{l}\text { Within } \\
\text { groups }\end{array}$ & 56754.609 & 88 & 644.939 & & \\
\hline Total & 62748.888 & 89 & & \\
\hline
\end{tabular}

Table $\mathrm{V}$ revealed significant differences in the academic performance of the younger and older Pre-degree students. In effect, younger students' performance was significantly better than the performance of older students. This was evident from Table VI.

\begin{tabular}{lccc} 
& \multicolumn{3}{c}{ Table VI } \\
& \multicolumn{3}{c}{ Age } \\
& & & \\
Younger & & $\mathrm{N}$ & $\mathrm{X}$ \\
Older & 52 & 181.87 \\
& 2 & 38 & 165.34
\end{tabular}


By referring to this table, the mean of the younger students was considerably higher than the mean of the older students.

d. Pre-degree II (83/84)

Table VII

Analysis of Variance

\begin{tabular}{llcccc}
\hline $\begin{array}{l}\text { Source of } \\
\text { Variation }\end{array}$ & $\begin{array}{l}\text { Sum of } \\
\text { Squares }\end{array}$ & DF & Mean Square & F & $\begin{array}{l}\text { Level of } \\
\text { Significance }\end{array}$ \\
\hline $\begin{array}{l}\text { Between } \\
\text { groups }\end{array}$ & 3542.016 & 1 & 3542.016 & 6.540 & 0.05 \\
\hline $\begin{array}{l}\text { Within } \\
\text { groups }\end{array}$ & 47657.629 & 88 & 541.564 & & \\
\hline Total & 51199.645 & 89 & &
\end{tabular}

This also followed similar trends shown in Pre-degree I 82/83. That is, there was statistically significant difference in the performance of younger and older students (see Table VII). Along the same line, Table VIII further elaborated on this.

\begin{tabular}{lccr} 
& & \multicolumn{2}{c}{ Table VIII } \\
& & Age & X \\
Younger & 1 & 54 & 154.44 \\
Older & 2 & 36 & 141.64
\end{tabular}

The mean of the younger students was higher than the mean of older students. This implied that, statistically younger students performed better than the older students in this category.

The data analysis revealed that in three of the four cases (sessions) younger students (17 years to 19 years) have consistently performed significantly better than the older students (20 years and above). That is, younger students performed better than the older students in Pre-degree I 81/82, Pre-degree I 82/83 and Pre-degree II $83 / 84$ but failed to establish significant differences in Pre- 
degree that older students will not significantly perform bettter than younger students was not supported in the three cases mentioned earlier except in Predegree II $82 / 83$.

The findings (in the three cases) have fallen in line with the earlier researches conducted on the relationship between age and academic performance. Intellectual and academic abilities have been found to be associated with age. Wechsler (1955) and Schaie and Strother (1968) found that younger students receive better education than older students and as one gets older, educational capabilities drop consistently. Tyler, (1965) also confirmea that intellectual powers continue to increase into early adulthood if adequate educational stimulation is provided. Kapur, (1972) found little difference in the performance of younger (17 years) and middle (18 and 19 years) student. He also found that a higher proportion of older students ( 20 years and above) failed or dropped out from school.

The poor performance of the older students could be attributed to the influence of problems related to the family responsibilities, job securement or the actual adjustment required for a student in the University (Isyaku, 1983). Older students might have also taken longer time in gaining sufficient entry requirements and are out of touch with academic pursuits after leaving Secondary or Teachers College (also noted by Itakura, 1962 and Kapur, 1972). Most of the younger students must have completed their secondary education not long ago and probably with less rate of failure or repetition. Continuous revision of syllabuses, break-through in knowledge, new techniques and materials might have not been enjoyed by the older students, hence they might not be acquainted with the new system.

However, the study revealed no significant differences in the performance of older and younger students in pre-degree II 82/83. But the mean of the younger students was slightly higher. Isyaku, (1983) also found no significant differences in the performance of younger and older students. However, younger students obtained high GPA in all cases.

Generally, these findigs did not confirm with the findings of Campbell (1965), Burns (1966), Von de Embse and Childs (1979) and Frerichs et al (1981), who reported that older students tended to be high achievers and more successful in Colleges and Universities.

\section{CONCLUSION:}

It could be deduced from the findings of the research that younger students in Pre-degree of Sokoto University perform better than the older students. However, it should be borne in mind that, age was the only variable considered 
in this research. Other variables could also influence the performance of the two categories of students. These variables may include socio-economic background of the students, post primary school attended, past experience, testtaking skills and so on. In essence, a follow-up study could be undertaken bearing in mind these variables to further ascertain the relationship between age and academic performance.

\section{REFERENCES}

1. Anastasi, A. (1976) Psychological Testing, Macmillan Publishing Company: Inc. New York.

2. Burns, R.B. (1966) 'Age and Mental ability: Retesting with thirty-three years' interval. British Journal of Educational Psychology 36, Page 116

3. Campbell, D. P. (1965) 'A Cross-sectional and longitudinal study of scholastic abilities over twenty-five years' Journal of Counselling Psychology, 12, Page 55 - 61.

4. Frerichs, A.H. (1981) 'Predicting Successful and Unsuccessful Developmental Mathematics students in Community Colleges. Paper presented at the annual meeting of the American Educational Research Association (Los Angeles, CA. April $13-17$ ).

5. Isyaku, K. (Ph.D., 1983) 'Academic Performance of Direct and Preliminary students of Bayero University Kano, Nigeria. Submitted at School of Education, Indiana University, August.

6. Itakura, K. (1962) 'On the relationships between the Entrance Examination Records and the Achievement Records of Science students in a certain University' Research Bulletin of the National Institute for Educational Research, Japan, No. 3, Page $23-26$.

7. Kapur, R.L. (1972) 'Student Wastage at Edinburgh University' Universities Quarterly Vol. 26, No. 3 Page 353 377

8. Scaie, K.W. and Strother, C.R. (1968) 'A cross-sequential study of Age Changes in Cognitive Behaviour' Psychological Bulletin, 70, Page 671 - 680.

9. Tyler, L. (1965) The Psychology of Human Differences Appleton-Century-Crafts, 3rd Edition.

10. University of Sokoto Regulation for Admission Into The University - University of Sokoto Calendar $1981 / 82$ 1982/83. page 94 .

11. Von de Embse, T. J. and Childs J.M. (1979) Adults in Transition: A Profile of older college students. Journal of College Student Personnel. 6, page 475 - 479.

12. W'chsler, D. (1955) Manual For the Wechsler Adult Intelligence Scale: New York: Psychological Corporation. 